\title{
SOLAR ENERGY IN SERBIA
}

\author{
T. Pavlovic ${ }^{1, *}$, D. Milosavljević ${ }^{1}$, M. Lambic ${ }^{2}$, V. Stefanovic ${ }^{3}$, \\ D. Mančić ${ }^{4}$, D. Piršs $l^{5}$ \\ ${ }^{1}$ Faculty of Sciences and Mathematics, University of Niš, \\ Višegradska 33, 18000 Niš, Republic of Serbia \\ ${ }^{2}$ Technical Faculty „Mihajlo Pupin“, University of Novi Sad, \\ Đure Đakovića bb, 23000 Zrenjanin, Republic of Serbia \\ ${ }^{3}$ Faculty of Civil Engineering, University of Niš, Aleksandra \\ Medvedeva 14, 18000 Niš, Republic of Serbia \\ ${ }^{4}$ Faculty of Electrical Engineering, University of Nis, Aleksandra \\ Medvedeva 14, 18000 Niš, Republic of Serbia \\ ${ }^{5}$ Faculty of Sport and Physical Education, University of Niš, \\ Carnojevića 10a, 18000 Niš, Republic of Serbia
}

\begin{abstract}
The paper focuses on development of solar energy, sun radiation potential and legislation regulating the use of sun radiation in Serbia. It also provides a description of the current state of affairs in the area of low temperature and photovoltaic conversion of sun radiation and solar architecture in Serbia. Special attention is paid to the development of solar energy in Nis, the description of the laboratories and the results of research in solar energy at the Faculty of Sciences and Mathematics, Faculty of Electrical Engineering and Faculty of Civil Engineering of Nis University.

Keywords: solar energy in Serbia, flat plate and compound parabolic collectors, PV solar plants, tracking PV system.
\end{abstract}

\section{INTRODUCTION}

Radiation of the Sun is being increasingly used worldwide to generate thermal and electrical energy. The main reasons for research, development and use of solar energy worldwide includes preservation of the existing ecological balance or its restoring where it is misbalanced, more efficient use of a country's potential to generate thermal and electrical energy, reduction of greenhouse effects, reduction of import and use of fossil fuels, and finally, development of the economy and local industry.

Development of solar energy in Serbia started with the work of prof. dr Branislav Lalović (19281988) in Belgrade and prof. Živojin Ćulum (19111991) in Novi Sad following the world energy crisis in 1973. Their were followed by prof. dr Miroslav Lambić (Technical Faculty „M. Pupin" in Zrenjanin), prof. dr Tomislav Pavlović (Faculty of Science and Mathematics in Niš), prof. dr Marija Todorović (Agricultural Faculty in Belgrade), prof. dr Marko Stojanović (Electrotechnical Faculty in Belgrade), prof. dr Milica Jovanović-Popović (Architectural Faculty in Belgrade), mr Mirjana Lukić (Institute of
Urbanism in Belgrade), dr Mila Pucar (Institute of Architecture and Urbanism of Serbia), dr Milan Pajević (Institute of Technical Sciences SANU), prof. dr Velimir Stefanović (Faculty of Civil Engineering in Niš), prof. dr Dragan Mančić (Faculty of Electronics in Niš), prof. dr Jasmina Radosavljević (Faculty of Occupational Safety in Niš), dr Zoran Todorović (Faculty of Sciences and Mathematics in Kosovska Mitrovica), dr Slaviša Đukanović from Mladenovac, dr Jovan Andrić (Technical Faculty in Čačak), prof. dr Aleksandra Krstić-Furundžić (Architectural Faculty in Belgrade), dr Vesna Kosorić (Belgrade), MA Lidija Radovanović (Faculty of Science and Mathematics in Niš), MA Slobodan Samardžić (Nišprojekt in Niš) and many others [1-4].

\section{POTENTIAL OF SUN RADIATION IN SERBIA}

Sun energy can take a vital place in the energy system of a country because it represents a renewable and inexhaustible energy source. From 
the point of the environment, the energy of the Sun is clean, and the energy technologies in exploitation do not pollute the environment.

Serbia has the average of about 272 sunny days and about 2300 sunny hours, which is more than the European average. The average intensity of sun radiation in the territory of the Republic of Serbia ranges from $1,1 \mathrm{kWh} / \mathrm{m}^{2} /$ day in the north to 1,7 $\mathrm{kWh} / \mathrm{m}^{2} /$ day in the south - during January, and from 5,9 to $6,6 \mathrm{kWh} / \mathrm{m}^{2} /$ day - during July. Annually, the average value of the overall sun radiation for the territory of the Republic of Serbia ranges from $1200 \mathrm{kWh} / \mathrm{m}^{2} /$ a year in the northwest Serbia to $1550 \mathrm{kWh} / \mathrm{m}^{2} /$ a year in the southeast Serbia, while in the middle part it is about $1400 \mathrm{kWh} / \mathrm{m}^{2} /$ a year.

The annual average of the daily global radiation energy on the horizontal plane is presented in Figure 1, and the annual average of daily global radiation energy on the plane oriented towards the south and tilted at a $30^{\circ}$ angle in relation to the horizontal surface is presented in Figure 2.

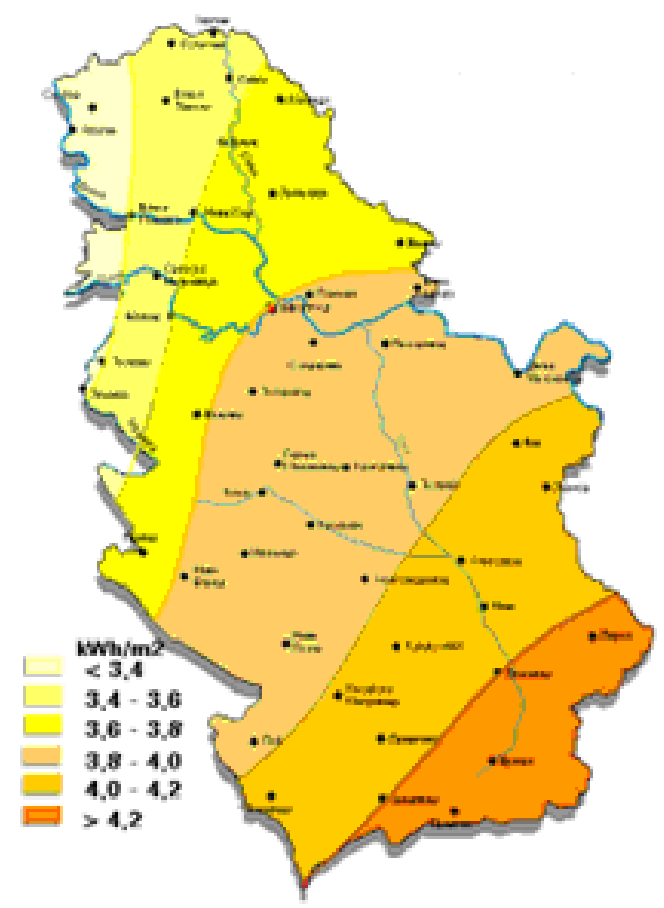

Figure 1. Annual average of the daily global radiation energy on the horizontal plane

Considering all the aforementioned one can conclude that Serbia has favourable conditions for use of solar energy and its conversion into thermal and electrical energy [5].

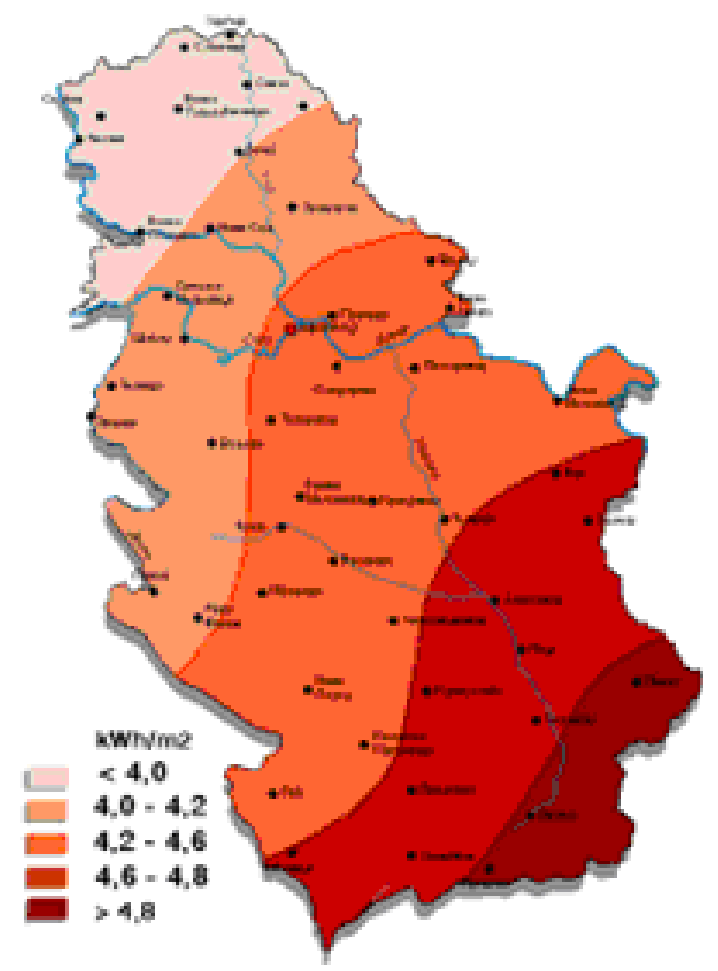

Figure 2. Annual average of daily global radiation energy on the plane oriented towards the south and tilted under the $30^{\circ}$ angle in relation to the horizontal plane

\section{LEGISLATION IN SERBIA}

The following legislation in the area of renewable sources of energy has been adopted in the Republic of Serbia:

- Law on Energy;

- Strategy on the Development of Energy in the Republic of Serbia till 2015;

- Program of the Implementation of Strategy of Development of Energy in the Republic of Serbia during the Period 2007-2012 (Changes and Amendments-November 2009);

- Regulation on the Requirements for the Eligibility of a Preferential Electrical Energy Producer and the Assessment Criteria for the Fulfilment of These Requirements;

- Regulation on Stimulative Measures for Electricity Generation Using OIE and Combined Production of Electrical and Thermal Energy;

- Model of the contract on supply of electrical energy from preferential producers.

Law on Energy of the Republic of Serbia was enacted on 24 July, 2004. This law defines the following: aims of the energy policy and the ways of its implementation, manners of the energy market organization and functioning, requirements in terms of timely, quality supply of electricity to the consu- 
mers and in terms of provision of safe, reliable and efficient electricity generation, networking system, managing the transport and distribution of electrical energy, securing smooth functioning and development of these systems, requirements for and manner of the implementation of the energy policy, requirements for energy efficiency and the environment protection while implementing energy policy and monitoring the implementation of this Law. Based on this Law, the following Agencies were established: Agency for Energy and Agency for Energy Efficiency.

The Regulation on Stimulative Measures for the Electricity Generation Using OIE and Combined Production of the Electrical and Thermal energy was adopted by the Government of Serbia on 20 November, 2009. This Regulation specifies the details of stimulative measures for the electricity generation using renewable sources of energy and supply of this energy, energy facilities designated for the production of electrical energy from the renewable sources, the contents of the contract on energy supply under stimulative measures, etc. The right to the stimulative measures defined by this Regulation in terms of the electrical energy produced in solar power plants is limited to the total installed power of up to 5MW. According to this Regulation, $1 \mathrm{kWh}$ of the electrical energy produced by solar power plant during a 12 year-period after contract signing will be paid to the producer at the price of 23 eurocents. Connection of the solar power plants or small solar power plants installed on private houses to the grid is regulated by the legislation of the EPS of the Republic of Serbia. Application of the Regulation in line with European Union legislation should contribute to the production of the electricity out of renewables in 2012 and its increase by $7,4 \%$, i.e. 735 million $\mathrm{kWh}$, compared to 2007. Among other measures, the Regulation defines the obligation of the EPS to take over all produced energy at the preferential prices. The Regulation on Amendments to the Program of the Implementation of Strategy on Development of Energy in the Republic of Serbia during the period 2007-2012 estimates that the energy potential and use of solar energy will be 0,6 million - annually.

In 2006 the Republic of Serbia ratified a contract on establishment of the energy association of EU and Albania, Bulgaria, Bosnia and Herzegovina, Croatia, Former Yugoslav Republic of Macedonia, Montenegro, Romania and Interim Mission of the United Nations in Kosova.

In September 2008 the European Parliament adopted legislation on climate changes with the aim to provide for a decrease of greenhouse effect by $20 \%$, an increase in the energy efficiency by $20 \%$ and the incorporation of the renewables of $20 \%$ in the total energy consumption in EU - by 2020, compared to 1990. The Republic of Serbia accepted the EU Directives on the use of renewable energy sources and is doing its utmost to implement them.

The Republic of Serbia became a member and the founder of the International Agency for the renewable sources of energy (IRENA) on 26 January, 2009.

A book that has been recently published by the Electric Power Industry of Serbia entitled The White Book of the Electric Power Industry of Serbia lists the EU legislation referring to the renewable energy sources, legal framework in Serbia related to the use of renewable energy and the possibilities of use of the renewable sources of energy in Serbia. The book contains the EU guidelines that envisage the reduction of greenhouse gas levels by $20 \%$, reduction of energy consumption by $20 \%$ and provision of $20 \%$ of needed energy from the renewable energy sources by the year 2020 .

Law on planning and installation was enacted in Serbia in 2009 ("Official Gazette of RS", no. $72 / 2009$ and 81/2009-corr.); it defines the conditions for the installation of solar systems for the heating of sanitary water, areas or drying of agricultural products [5-6].

\section{LOW TEMPERATURE CONVERSION OF SUN RADIATION IN SERBIA}

Flat collectors with water or air are used for low temperature conversion of sun radiation. Flat collectors with water are used to heat water in households, hotels, hospitals, industrial facilities, swimming pools, etc. Flat collectors with air are used to heat room air. Integral solar collectors are an integral part of a facility on which they are mounted (roof, vertical walls, etc). They are easily incorporated into architectural units, are multipart, well isolated on the bottom (lying on the roof isolation or leaned against the wall). In previous research in Serbia all attention was focused on the development of low temperature collectors with spectrally selective absorber of sun radiation (B. Lalović, T. Pavlović), air collectors (M. Lambić), hybrid collectors (B. Lalović, T. Pavlović,) etc [1-4,7-9].

\subsection{Market and design of solar systems for low-temperature conversion}

During the period 1978 - 1985 Serbia had numerous manufacturers of flat collectors of sun radiation such as: Nissal in Niš, Šinvoz in Zrenjanin, 
Petar Drapšin in Novi Sad, Goša in Smederevska Palanka, Jugoterm in Gnjilane, etc. After 1985 there was a decline in the manufacturer's interests for the production of solar collectors, so that currently, the flat collectors with water are manufactured by Agrosistems in Niš, Termovent in Belgrade, Elsol in Požarevac, KMont d.o.o. in Petrovaradin etc.

Design and mounting of solar installations nowadays is part of the production line of the companies Energo Pro-Teh in Zrenjanin, Termogas in Senta, Conseko d.o.o. in Belgrade etc. Solar boilers and differential thermostats are produced by several private companies.

In Serbia flat collectors with water are used for heating of sanitary water in private households, hotels, hospitals, military and other facilities.

\subsection{Examples}

There are several installed solar systems with flat collectors for water heating in Serbia: on General hospital in Požarevac (210 collectors), in Stamnica near Petrovac na Mlavi (80 collectors), on Youth home in Kragujevac (20 collectors), on Special asylum hospital in Kovin (30 collectors), on Special asylum hospital in Vršac (30 collectors), on Special asylum hospital in Novi Kneževac (30 collectors), on Sports center in Kikinda (40 collectors), etc.

During the period 2006 to 2009 solar collectors for heating of sanitary water were installed on Food and catering school and on nurseries Sunce, Bambi and Lugovi in Čačak. This Project was successfully implemented by the Center for renewable sources of energy of Greece-CRES/KAPE (Athens), ECONET (Athens), NGO, expert network and the town of Čačak. Project was financed by the Ministry of Foreign Affairs of the Republic of Greece through the program HELLENIC AID, with smaller financial participation of the project partners. Project leader was Center for renewable sources of energy (Athens).

In Obrenovac solar collectors for water heating are installed on: Youth Sports home $(27$ collectors, $3 \mathrm{~kW}$ ), on Obrenovac swimming pools (40 collectors) and on Daily care for disabled children (5 collectors).

At the beginning of 2009 the Provincial Secretariat for energy and mineral raw materials of Vojvodina signed with the Slovak Agency for international help for development (SAMRS) a contract on the implementation of the project Solar energy for Vojvodina, and the Slovak state and the company Thermo Solar Žiar from Slovakia contributed to the donation. Thanks to this project, at the end of Octo- ber 2009, 200 solar collectors for heating of sanitary water were installed on Zrenjanin's general hospital Dr Đordje Jovanović (Fig.3) and 80 solar collectors on Youth home Angelina Kojić - Gina (Figure $4)$.

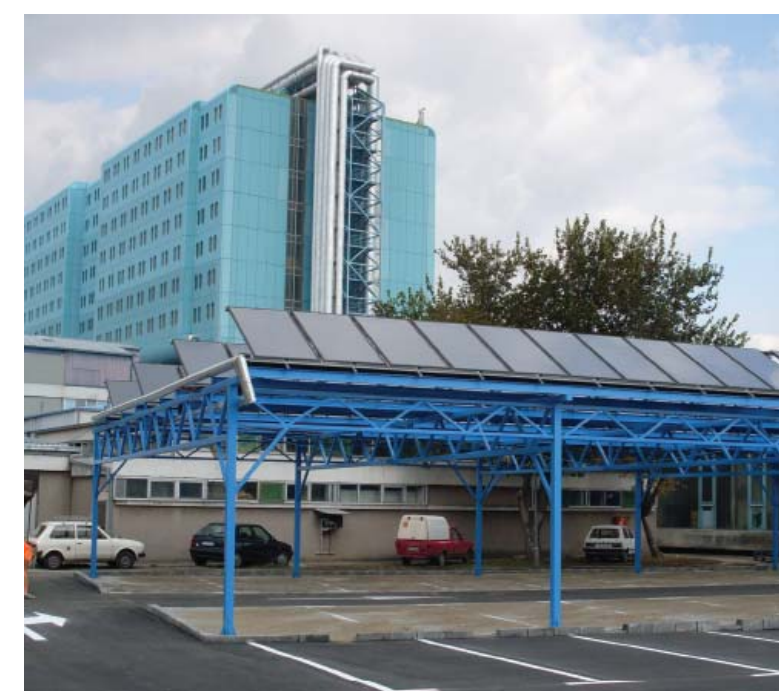

Figure 3. Solar collectors in Zrenjanin's hospital Dr Đorđe Jovanović

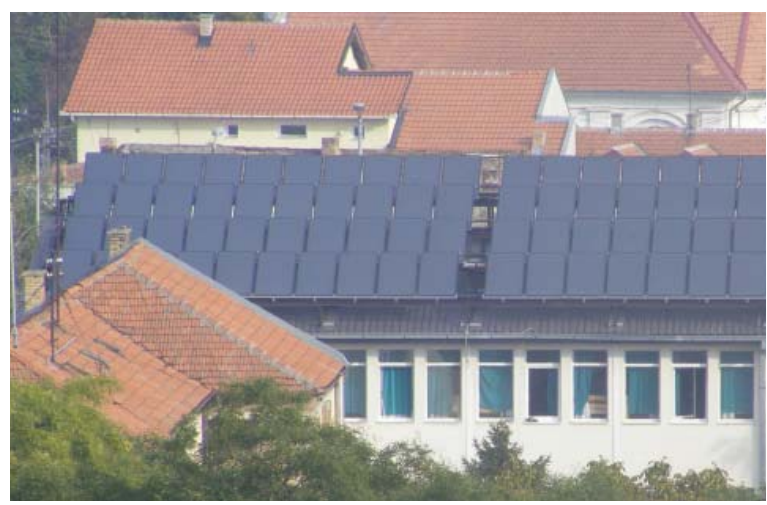

Figure 4. Solar collectors on the roof of Youth home Angelina Kojić Gina in Zrenjanin

At the end of 2009, day care for disabled children Kolevka in Subotica started a big project of the substitution of the conventional types of energy in local electro-energy and heating system by the solar energy in the decades to come. The care center installed a solar system with 160 collectors for heating of sanitary and technology water and for additional heating of the building during the days in seasonal transitional periods when the central heating system is not in function.

In 2010, thanks to the donation of the Government of the Kingdom of Spain, 10 flat collectors for the heating of the sanitary water were installed on the asylum hospital in Toponica. 
In 2011, 96 flat collectors were installed on the roof of the city hospital in Pirot. Solar system can be combined with and powered by electricity and crude oil but it can also be used autonomously to heat water for heating and kitchen consumers, sterilization, laundry, etc. [1-4,7-9].

\section{PHOTOVOLTAIC CONVERSION OF SUN RADIATION IN SERBIA}

Solar cells made of monocrystalline, polycrystalline and amorphous silicon and other thin layer materials are used for photovoltaic conversion of sun radiation. Solar cells are mostly used for generation of electrical energy in households in small PV solar plants with 1-2 kW of power, mounted on the roofs or facades of the buildings and other built structures, etc. PV solar plants can function independently from the grid or can be connected to it. Depending on the constituent components a PV solar plant which is not connected to the grid can supply the consumers with AC or DC.

The area of photovoltaic conversion of sun radiation was thoroughly researched by M. Mihailović, Lj. Pešić (IHTM - Center for microelectronic technologies and monocrystals, Belgrade), B. Lalović, T. Pavlović, M. Stojanović, Z. Todorović, etc. First solar cells were made in 1963 in IHTM in Belgrade of monocrystalline silicon with the efficiency of $8 \%$; for the sake of comparison, in these days solar cells on the satellites had a $10 \%$ efficiency. During the period 1978-1981 in the company Radio cevi $E i$ in Niš low efficiency solar cells of monocrystalline silicon with and small power solar modules were produced.

\subsection{Market and design of the photovoltaic systems}

Solar modules, charging regulators for the batteries, batteries and invertors can be purchased nowadays in Serbia in several private companies: Telefon Inžinjeringa in Zemun, Elvit in Pirot, Conseko d.o.o. in Belgrade, etc. Design of PV systems in Serbia is performed in Netinvest (Belgrade), Conseko d.o.o. (Belgrade), etc.

\subsection{Examples}

Solar cells in Serbia are used in the Republic hydrometeorological institute for supplying hydrometeorological devices with electrical energy, for the operation of the signalling equipment (traffic lights, speed measuring devices for cars, etc.), for electrical energy generation in private households, etc.

During the NATO pact aggression T. Pavlović with other experts from the Factory of professional electronics Ei and from Nissal in Niš installed solar cells on mobile radio stations of the Yugoslav Army.

Until now four PV solar plants have been installed in Serbia: on the premises of the elementary school Dušan Jerković in Ruma (3 kWp, 2004.), in the secondary school in Varvarin $(5 \mathrm{kWp}$, 2010.), in the secondary electro-technical school Rade Končar in Belgrade $(5 \mathrm{kWp}, 2010$.) and in technical college Mihajlo Pupin in Kula $(5 \mathrm{kWp}$, 2010). PV solar plants in Varvarin, Belgrade and Kula were installed thanks to the donations of the Government of Spain and through the Agency for the Energy Efficiency in Belgrade within the Project Development of the installations for the promotion and use of solar energy in Serbia.

In 2011 the Republic of Serbia started building $2 \mathrm{~kW}$ PV solar plants on the roof of the Faculty of Sciences and Mathematic in Niš. In 2011, and a dual-axis tracking $950 \mathrm{kWp}$ PV solar plant with solar modules made of polycrystalline silicon was installed in the village of Velika Biljanica, near Leskovac.

At the end of June, 2011 the construction of the first PV solar plant bigger than $1 \mathrm{MW}$ started on the Mount of Zlatibor. The main project coordinators and investor in the construction of this plant, the power of which, after the completion of the project will be $5 \mathrm{MW}$, are the following companies Dunav osiguranje and Elektroprivreda of Serbia, in cooperation with the Municipality of Čajetina. Total amount of the investments is around 15 million euro (3 million for MW), and in the first phase $1-1,5$ million euro will be invested. .

In Merdare near Kuršumlija the plan is to construct a 2 MW PV solar plant in the area of around 4 ha. This project will be financed by the Italian company "Multienerdži" and the local authorities in Kuršumlija, with the participation of the representatives of EPS and it will cost around 5 million euro.

The contract on installation of a $150 \mathrm{MW}$ PV solar plant in the area of 500 ha in the territory of Vranje, was signed by the Mayor of Vranje and the director of the private company from China Euro Solar Park on 12 September, 2011. Construction of this plant is planned for April, 2012. The project will cost 300 million euro [1-4,7-8,10-12]. 


\section{SOLAR ARCHITECTURE IN SERBIA}

Contemporary solar architecture is based on the direct (passive), indirect (active) and combined (passive and active) intake of sun radiation. Direct intake of sun radiation implies an intake by the given object itself without any additional equipment for intake of sun radiation and its transformation into other types of energy. Indirect intake of sun radiation is an intake performed by the equipment that is added to the given object on which thermal (collectors), photovoltaic (solar cells) or thermal and photovoltaic (hybrid collectors) conversion of sun radiation is performed. The combined intake of sun radiation means intake which is performed by the given object as a passive receiver and the additional devices (collectors and solar cells) as the active receivers of the sun radiation.

The following persons have been active in the field of solar architecture in Serbia: B. Lalović, M. Lambić, M. Jovanović-Popović, M. Pajević, M. Pucar, M. Lukić, and others. Furthermore, up to now several houses with passive solar intake have been built in Serbia: in Kać, Mladenovac, Belgrade, Sombor, Zaječar, Ljig, Novi Sad, etc. [1-4,7,13-14].

\section{SOLAR CENTERS IN SERBIA} Belgrade.

Solar centers in Serbia are Niš, Zrenjanin and

Research in solar energy is conducted in the Laboratory at the Faculty of Sciences and Mathematics, Faculty of Civil Engineering, and Faculty of Electrical Engineering in Niš.

Since 1973 a total of eight symposia and scientific conferences on solar energy have been held in Serbia, the first one in Belgrade, in 1978 (The International Solar Energy Symposium on Technical, Economical and Organizational Aspects) and the last one in 1999 in Zrenjanin (Scientific conference on solar energy). Besides the aforementioned conferences, our experts participated with their papers on solar energy in international conferences addressing the energy, technique, environment protection, etc. Several doctoral dissertations, master theses and diploma papers in the area of solar energy were defended in Serbia, and many books published. [1-4].

\section{SOLAR ENERGY IN NIŠ}

Development of solar energy in Niš began when prof. dr Branislav Lalović moved to Niš in
1974 as an associate professor working at the Department of Physics at the Faculty of Philosophy. Prof. dr B. Lalović gave a course on nuclear physics at the Faculty of Philosophy, where he also developed flat collectors of sun radiation in the company Đuro Salaj in Niš. In order to obtain the most sophisticated sun radiation absorber, prof. dr B. Lalović recommended his associate T. Pavlović to prof. $\mathrm{dr}$ Alex Ignatiev in Huston to begin his doctoral dissertation. At the Department of Physics, University of Huston T. Pavlović investigated optical and microstructural properties of spectrally selective absorbers of sun radiation on electrochemically coloured anodic oxidized aluminium. He defended his doctoral dissertation in 1986 at the Electrotechnical Faculty in Belgrade. Thanks to the obtained results in this dissertation and a successful cooperation of prof. $\mathrm{dr}$ B. Lalovic with the experts in the company Đuro Salaj in Niš, a thermal collector with spectrally selective absorber of sun radiation was made, which, by its characteristics, is among the better ones in the world.

Besides this, under the supervision of prof. $d r$ B. Lalović, at the Faculty of Philosophy and in Nissal in Niš, a hybrid collector with solar cells made of amorphous silicon on glass was created and solar cells of amorphous silicon on aluminium were formed and investigated.

Under the guidance of T. Pavlović in the Company for Professional Electronics Ei in Niš, during the period 1986 to 1999 , the research focused on formation of the battery charger regulator, inverter (convertor of the DC into AC), device for the automatic direction of solar cells towards the Sun, etc. $[1-2,4,15-16]$.

\subsection{Solar Energy Laboratory at the Faculty of Natural Sciences and Mathematics in Niš}

Solar Energy Laboratory at the Department of Physics, Faculty of Natural Sciences and Mathematics in Nis was founded in 2003 and it comprises two rooms on the fifth floor and on the Faculty roof.

In the smaller room on the fifth floor there is a 120 lit. solar boiler, calorimeter MULTICAL 401 (KAMSTRUP from Denmark, Fig.5), water flow measuring device (INSA PUPIN from Belgrade), solar module for forced water circulation with a circulation pump, expansion vessel, thermometers, manometer and adequate valves, differential thermostat (Fig.6), a device for determination of electric solar cells characteristics MINI KLA (Ingenieurburo Mencke\&Tegtmeyer from Germany), and NIGOS (from Niš), charging battery regulators, batteries, 
neon lamps, computers, printers and other measuring instruments.

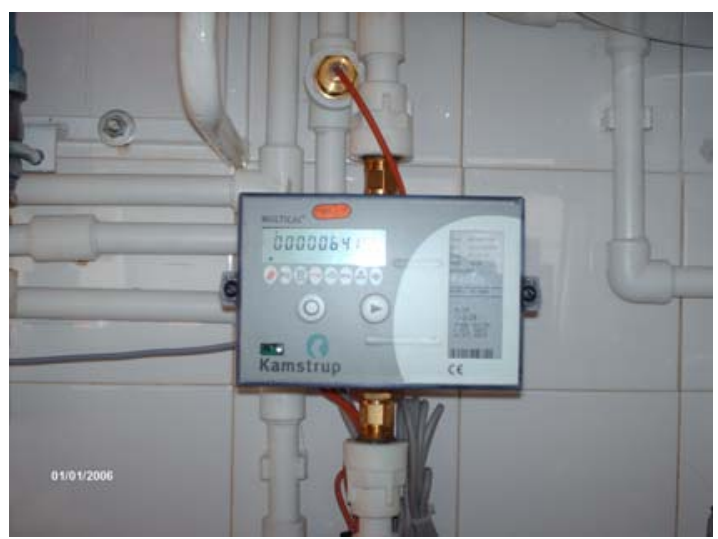

Figure 5. Calorimeter Multical 401

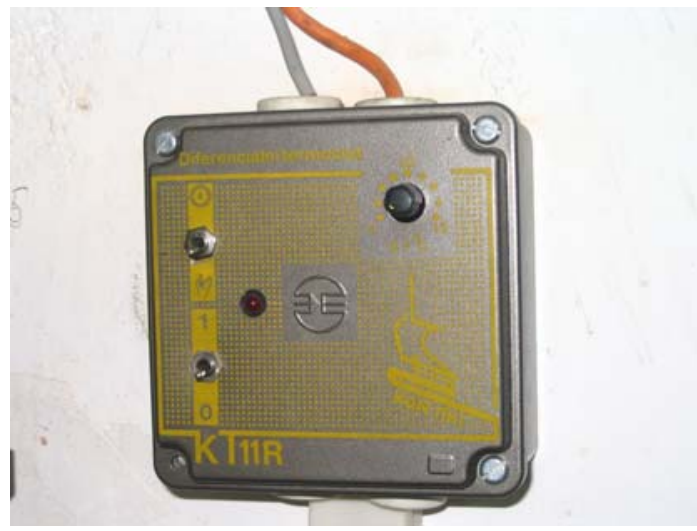

Figure 6. Differential thermostat

In a larger room on the fifth floor (Figure 7 and Figure 8) there is a 80 lit. solar boiler, calorimeter MULTICAL 66C22F1124 (KAMSTRUP), solar module for forced water circulation with a circulation pump, expansion vessel, thermometers, manometer and adequate valves. Besides, there are also a new NIGOS measuring system, Mini-KLA and KLA devices (Ingenieurburo Mencke\&Tegtmeyer from Germany, Figure 9 and 10), for determination of electric characteristics of PV modules and hybrid collectors of solar radiation. For the measurement of the solar radiation intensity a pyranometer KIPP ZONEN CM22 (from Netherlands, Figure 11) is used. Laboratory also has UV pyranometer $U V B-1$ (AERO LASER Germany, Figure 12).

Besides, in the larger room on the fifth floor there are solar invertors of DC into AC Sunny Boy 2000HF (SMA Solar Technology AG, Germany, Figure 13), SUNNY WEBBOX with Bluetooth (SMA Solar Technology AG, Germany, Figure 14) and SUNNY SENSORBOX (SMA Solar Technology AG, Germany) which is used for research of energy efficiency of the photovoltaic solar plant of $2 \mathrm{~kW}$.

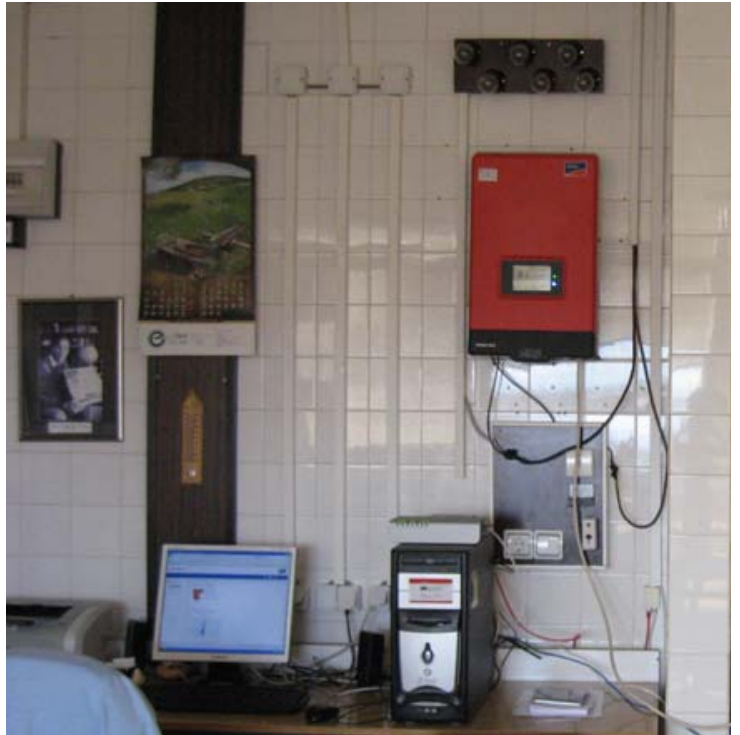

Figure 7. Part of the interior of Solar Energy Laboratory with inverter and SUNNY WEBBOX

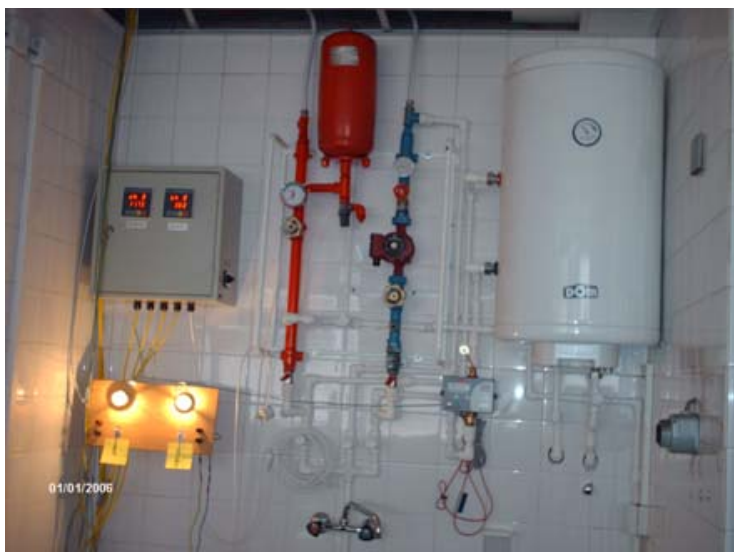

Figure 8. Part of the interior of Solar Energy Laboratory with system for determination of thermal and electrical characteristics of hybrid collector

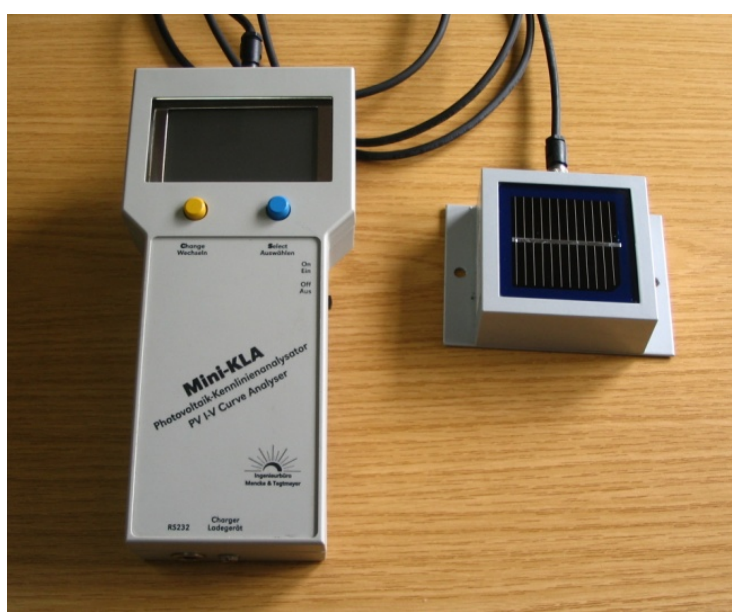

Figure 9. MINI KLA Equipment for Solar Intensity and Solar Cells Photovoltaic Characteristics Measurement 


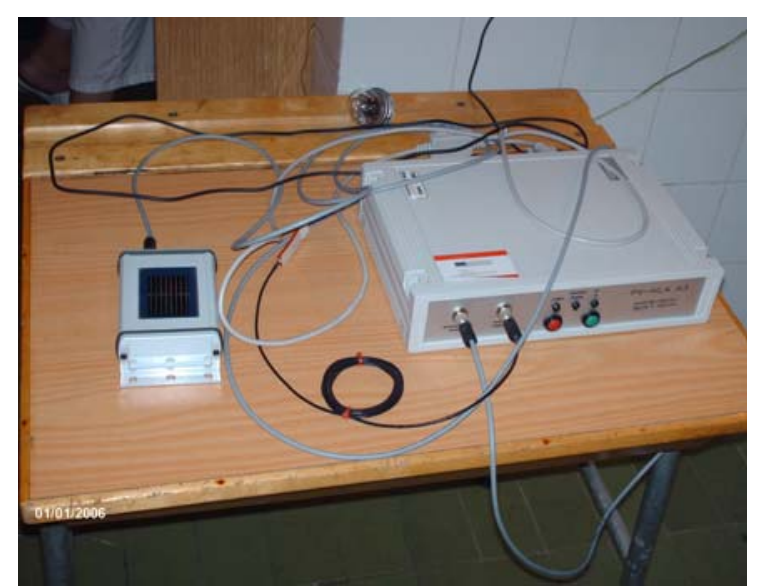

Figure 10. KLA device (Ingenieurburo Mencke\&Tegtmeyer from Germany)

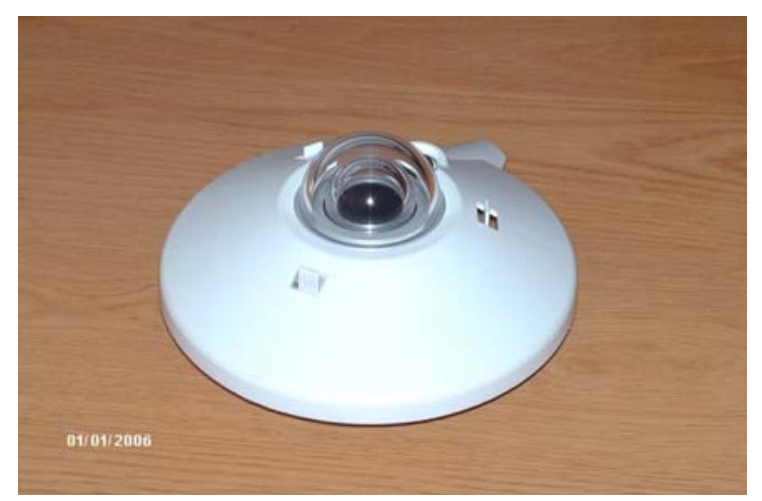

Figure 11. Pyranometer KIPP ZONEN CMP22 UV

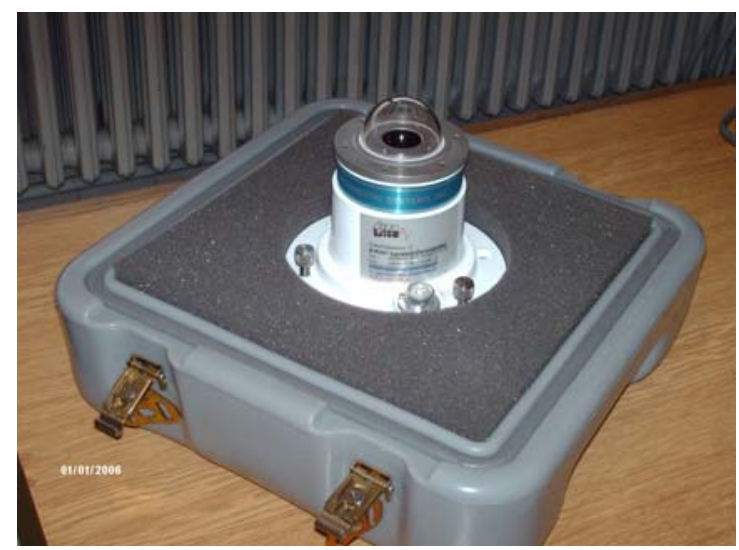

Figure 12. Pyranometer UVB-1 (Aero Laser-Nemačka)

On the Faculty roof a movable and static base for the collectors is mounted, that can be adjusted in relation to the horizontal axis from 0 to 90 degrees. On the bottom of the static base there is a thermal collector with uncolored absorber, uncolored and spectrally selectively colored absorber. On the upper moveable base there is a solar module with solar cells made of monocrystalline silicon, hybrid collector with solar cells made of monocrystalline silicon, hybrid collector with solar cells made of amorphous silicon on glass and thermal collector with spectrally selective absorber. On separate bases there are thermal and hybrid collectors with flat concentrators of solar radiation. Thermal sensors for the measurement of incoming and outgoing water temperature are mounted on collectors. Thermal sensors are connected to a computer by means of a digital meter, thus the results are processed in forms of tables and graphics. A PV 55W module whose position can be changed around the vertical and horizontal axis is placed on the rotational basis (Figure 15, 17 and 18).

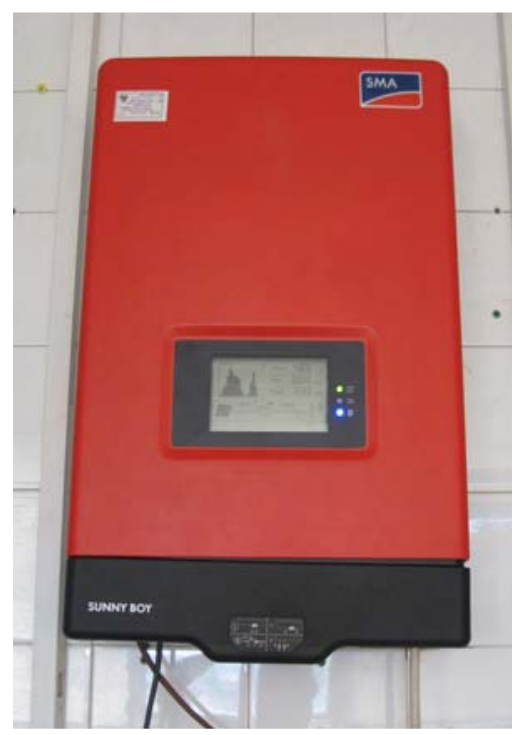

Figure 13. Solar inverter SUNNY BOY 2000HF (SMA Solar Technology AG, Germany)

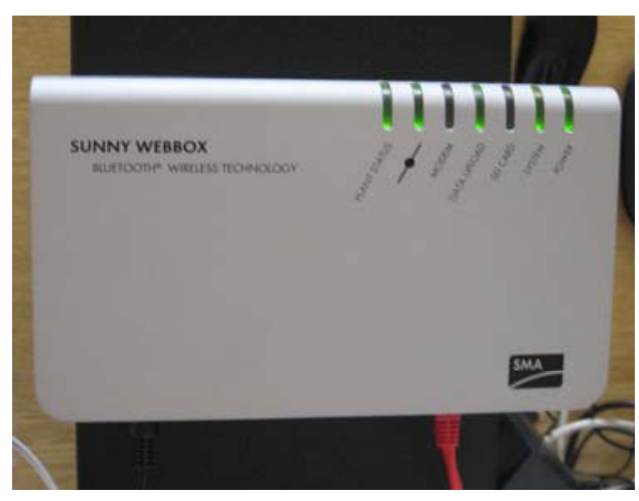

Figure 14. SUNNY WEBBOX with Bluetooth (SMA Solar Technology AG, Germany)

On the Faculty roof, apart from the collectors, there is a meteorological station VANTAGE PRO (DAVIS from USA, Fig.20), meteorological station built in Novi Sad and the pyranometer. Acquisition of meteorological parameters is performed every 10 minutes. Of meteorological parameters, the following are continuously measured and registered: air temperature, solar radiation intensity, UV index, 
pressure, air humidity, wind velocity and direction, etc. Adequate software is designed for the processing of thermal and electrical parameters of solar equipment. All investigations are carried out in accordance with the local and world solar radiation standards.

Apart from that on the roof of the Faculty, there are array connected solar modules of monocrystalline silicon (ISOFOTON, Spain, Fig.16), with total power of $600 \mathrm{~W}$, which are a part of a PV solar plant installed on PMF in Niš. Investigation of the energy efficiency of $2 \mathrm{~kW}$ PV solar plant is conducted within the research project TR33009 financed by the Ministry of Science of the Republic of Serbia during the period 2011-2014.

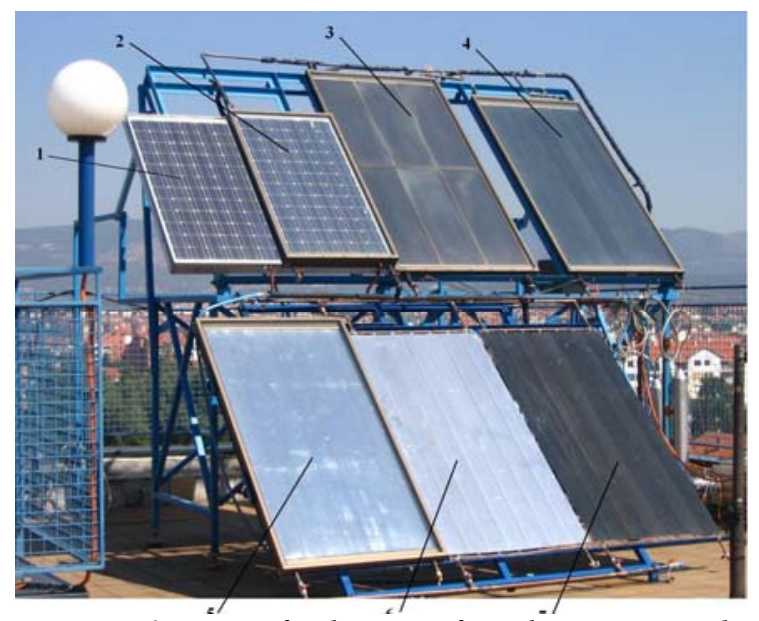

Figure 15. Part of Laboratory for solar energy on the roof of the Faculty of Science and Mathematics in Nis: 1) solar module, 2) hybrid collector with solar cells made of monocrystalline silicon, 3) hybrid collector with solar cells made of amorphous silicon, 4) flat collector with spectrally selective absorber, 5) flat collector with noncoloured absorber, 6) non-coloured absorber, 7) spectrally selective absorber

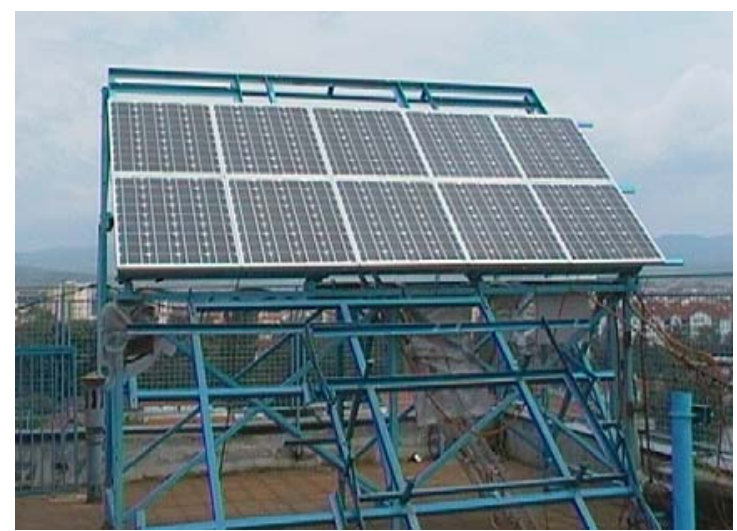

Figure 16. PV solar plant of $600 \mathrm{~W}$ with monocristalline silicon solar modules on the roof of the Faculty of Science and Mathematics in Niš

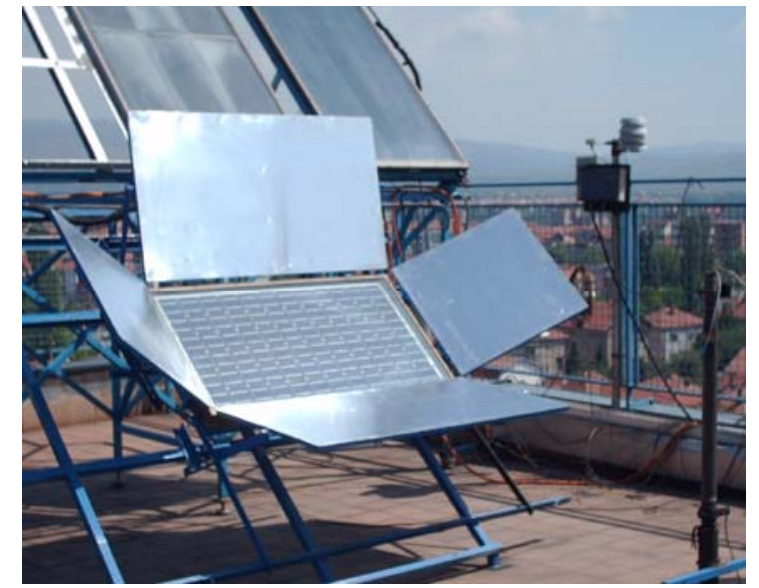

Figure 17. PV/Thermal Collector with flat concentrators of sun radiation

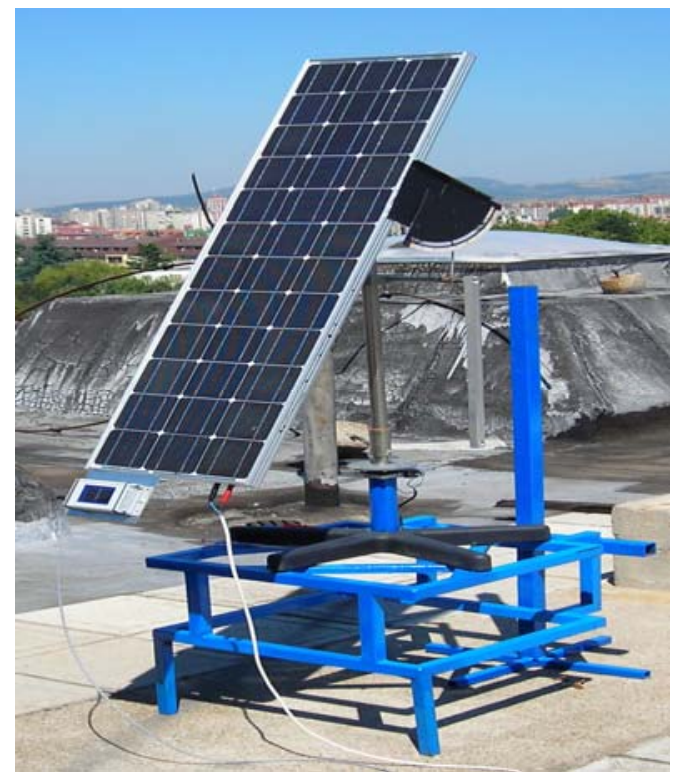

Figure 18. Rotating PV module with monocrystalline silicon solar cells

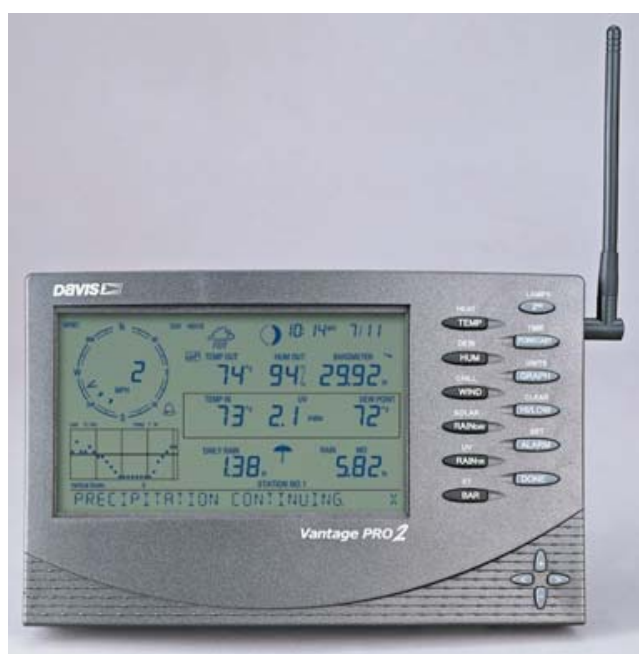

Figure 19. Central Unit Automatic Davis Meteorology 


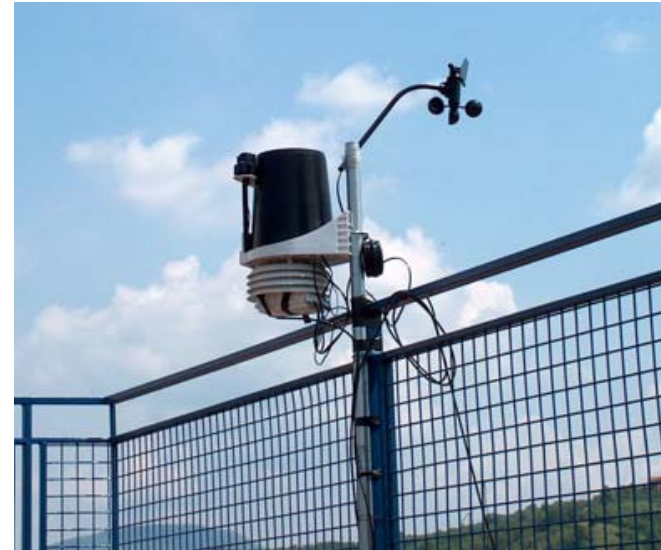

Figure 20. Automatic Davis Meteorology Station

T. Pavlović together with his associates received, on $16^{\text {th }}$ of November, 2007, from WUS AUSTRIA the award for the WUS CDP+ Project in the category for the best content.

In the Laboratory for solar energy at the Faculty of Science and Mathematics in Nis the following international projects were realized: Development of Solar Energy, Astronomy and Meteorology Laboratory (WUS project, 2003-2004), Physics and Techniques of Solar Energy (WUS $\mathrm{CDP}^{+}$project, 2006-2007), Energy efficiency and environmental awareness. Experimentation and training for a self-sustainable local development (E.CO.LOC. project, 2007/08) and Renewable energy sources as a model of sustainable development of the countries of West Balkans (UNESCO project, 2010-2011). Besides, in the Laboratory for solar energy at the Faculty of Science and Mathematics in Niš, the following projects, financed by the Ministry of Science and Technological Development of the Republic of Serbia, were realized: Development and investigation of hybrid flat receiver of solar energy for thermal and electrical conversion, Development and application of photovoltaic solar systems as the sources of light in the individual housing objects, Atlas of the energy potential of the Sun and the wind of Serbia, Development and investigation of thermal and hybrid collector with the sun radiation concentrator and Investigation of the energy efficiency of the PV solar plant of $2 \mathrm{~kW}$.

8.2. Laboratory for thermal technique, thermal energy and processing techniques at the Faculty of Civil engineering in Niš

Laboratory for thermal technique, thermal energy and processing techniques at the Faculty of Civil Engineering in Niš was established in 2004.
Laboratory is composed of one room at the Faculty and the area on its roof (Figure 21, 22 and 23).

Laboratory conducts hydraulic and thermotechnical investigations of the flat collectors with liquid and compound parabolic collectors for middle temperature conversion of sun radiation.

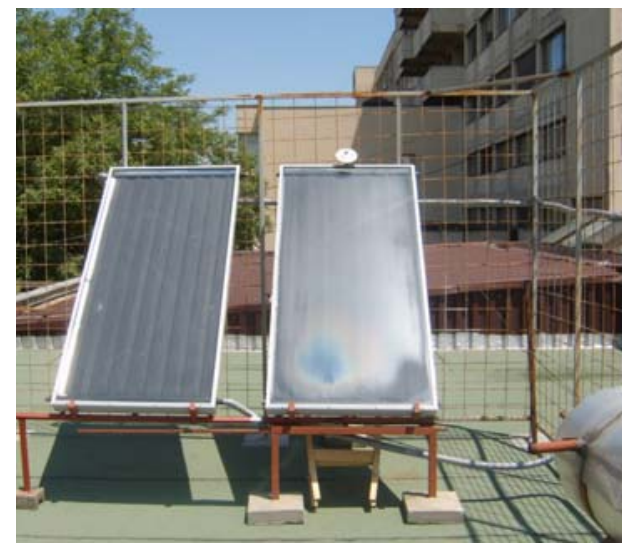

Figure 21. Flat collectors on the roof of Civil Engineering faculty in Niš

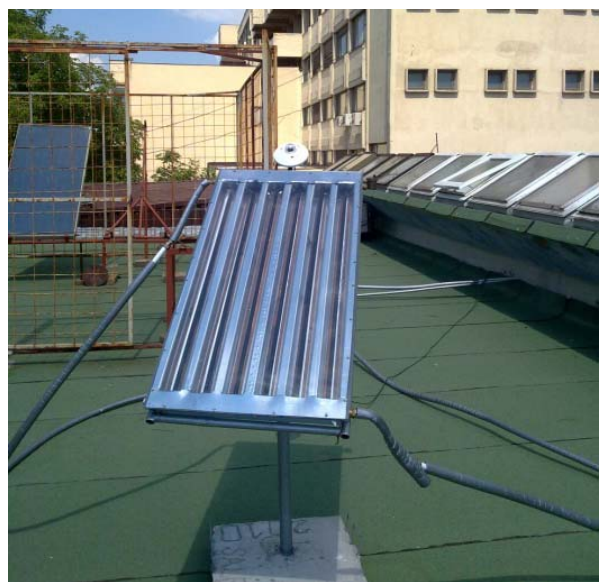

Figure 22. Compound Parabolic Collector- CPC-2V for middle temperature conversion of sun radiation into thermal on the roof of the Faculty of Civil Engineering in Niš

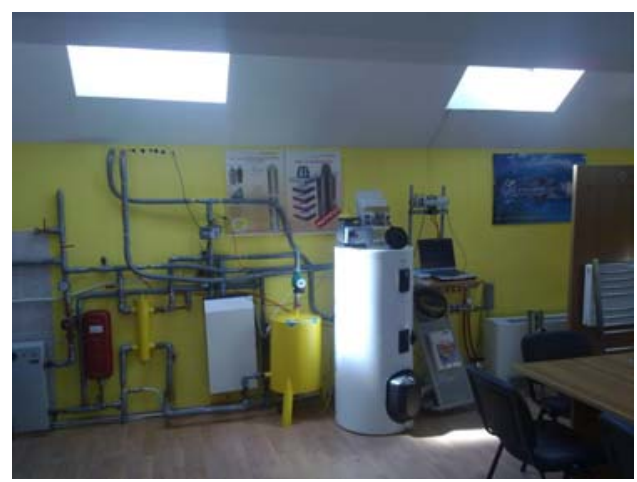

Figure 23. Device for the testing of flat and compound parabolic collectors in the Laboratory at the Faculty of Civil Engineering in Niš 
Laboratory performs temperature measurements by temperature sensors Pt500, or previously calibrated thermo-pairs chromel-alumel, with 0,2 $\mathrm{mm}$ in diameter. "Cold" ends of all thermo-pairs are immersed into thermostatic vessel with the mixture of water and ice. For the determination of voltage of thermo-pairs, a voltmeter Hewlett-Packard $3468 \mathrm{~A}$ is used. Ambient temperature is measured by the measuring system TESTO 454 and is checked by mercury thermometer.

Wind streaming speed, relative humidity and temperature, as the relevant parameters for the ambient state description are determined in the Laboratory by means of TESTO 454 measuring system with anemometer probe and the probe for the measurement of relative humidity and temperature (Figure 25). According to the manufacturer's declaration, the precision of the mentioned probes is $1 \%$. On the basis of the measured values, calculation and display of the values of absolute humidity is preformed by the measuring system TESTO 454, i.e. its software.

Measurement of the direct and diffuse sun radiation is performed in the Laboratory by pyranometer Kipp\&Zonen CM11 (Figure 24). Pyranometer has the range of radiated energy from $0 \div 1400 \mathrm{~W} / \mathrm{m}^{2}\left(\max .4000 \mathrm{~W} / \mathrm{m}^{2}\right)$ and registers the sun radiation in the range of wavelengths from $305 \div 2800 \mathrm{~nm}$. Sensibility of the pyranometer ranges from $4 \div 6 \mu \mathrm{V} /\left(\mathrm{W} / \mathrm{m}^{2}\right)$.

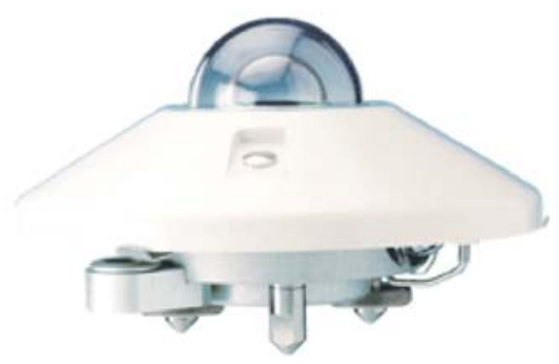

Figure 24. Pyranometer Kipp\&Zonen CM11

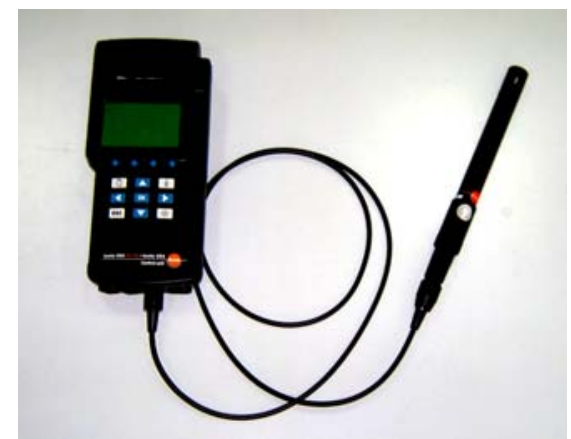

Figure 25. Measuring system TESTO 454 with probe for measurement of humidity and temperature
Laboratory measures liquid flow speed through the solar system by means of TA-STAD measuring valve and $T A-C B I^{I I}$ acquisition system of the company Computerized Balancing Instrument, flow measurer Krohne H250 and calorimeter Kamstrup Multical 66CDE (Figure 26, 27 and 28).

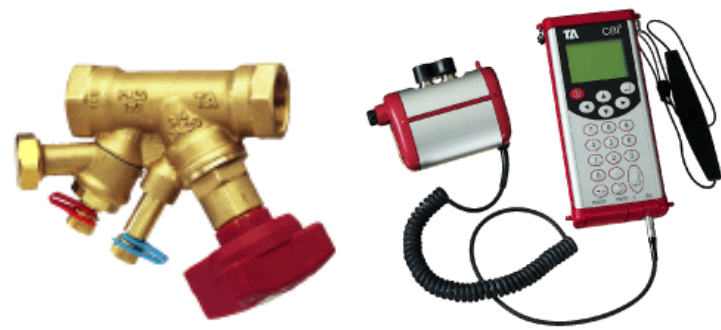

Figure 26. TA-STAD measuring valve (left) and acquisition system TA-CBI $I^{I I}$ (right)

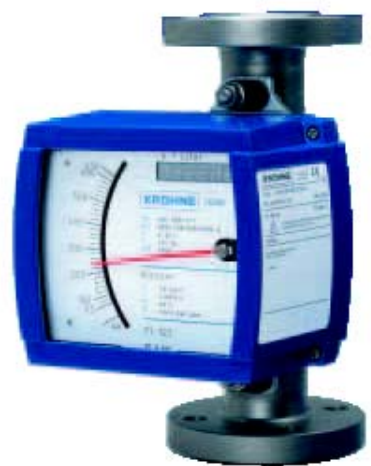

Figure 27. Flow measurer Krohne H250

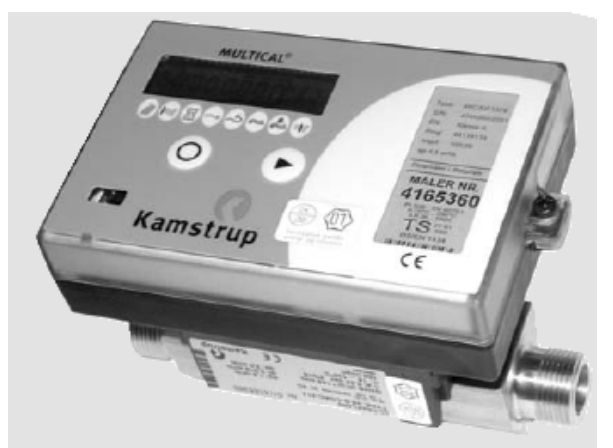

Figure 28 . Calorimeter Kamstrup Multical 66CDE

The following project was carried out by the Laboratory for thermal technique, thermal energy and processing techniques at the Faculty of Civil Engineering in Niš, in the period 2004-2005: Development of the new generation of solar receivers for low and middle temperature conversion of sun radiation into heat and the application on the prototype of the family housing object with hybrid passive and active systems to use the sun energy, which was financed by the Ministry of Science and Technological Development of the Republic of Serbia. 
In 2011 the Laboratory conducted Investigation and development of energy and ecology highly effective systems of polygeneration based on renewable energy sources within the project financed by the Ministry of Science and Technological Development of the Republic of Serbia.

\subsection{Laboratory for energy electronics at the} Faculty of Electrical Engineering in Niš

The research subject of the Laboratory for energy electronics at the Faculty of Electrical Engineering in Niš includes rotational solar systems (positioners) for the optimal intake of the sun radiation, and the accompanying measuring systems for monitoring different parameters.

Research of rotational solar systems for the optimal intake of the sun radiation is conducted within the framework of the projects financed by the Ministry of Education and Science: Development, investigation and comparative analysis of rotating and stationary receivers of sun radiation (20062009) and Development, realization, optimization and monitoring of the network modular rotating photovoltaic $5 \mathrm{~kW}$ system power (2011-2014).

During the past years the research focused on the following:

- Creation of own algorithm and mathematical model for the monitoring of the apparent Sun motion for a defined position on the Earth's surface, based on the basic principles of solar geometry;

- Creation and verification of the laboratory prototypes of original measuring systems with one and dual axis of rotation for real time operation;

- Formation of meteorological, multipurpose station positioned at a remote location;

- Realization of several measuring systems: for the measurement of the direct sun radiation intensity, measurement of temperature and currency of PV module and for the determination of their absolute position;

- Realization of two active thermovision several measuring methods for the investigation of the defects of photovoltaic module;

- Realization of new Matlab and PSpice models of photovoltaic modules;

- Realization of several variants of easy positioners for the optimal intake of the sun radiation;

- Development, realization, optimization and monitoring of network modular, rotating photovoltaic system, power of $5 \mathrm{~kW}$.
In the text below, some of the most important results obtained in the Laboratory for energy electronics at the Faculty of Electrical Engineering in Niš are presented.

Description of the mechanical construction of the realized measuring rotating system with dual axis of rotation for the determination of the global sun radiation intensity is presented in Figure 29a. Realization of the measuring rotating system is performed by use of a step motor, with the monitoring of dual-axis measuring rotating system into a defined position realized by means of microcontrollers. Rotation of the system is performed by revolving of the receiving area around two mutually perpendicular axes. Thus, during monitoring the path of the Sun, the receiver of the sun radiation can be directed towards any given point in the sky. The capacity of the realized two-axis measuring system is maximum $5 \mathrm{~kg}$ and it is adjusted to the rotation of different measuring etalon instruments, such as pyranometers, pyrheliometers, CCD cameras, etc.

On the platform whose movement is controlled by the realized device, a pyranometer CM11 manufactured by Kipp\&Zonen was mounted to measure the intensity of the global sun radiation in the rotating area. The managing algorithm is realized in such a manner that the device after each rotation and measurement on a defined position of the Sun's path for one-axis, and then, for two-axis system, before rotating and assuming new position, is directed towards the south, then radiation intensity is read as if this were a stationary device with a $45^{\circ}$ tilt. There is an obvious increase in the intensity of global radiation during the observed day in the year, in oneand two-axis measuring system in comparison with the stationary system (Fig. 29b). Also, by means of dual axis system in the receiving area, a higher intensity of the global radiation compared to oneaxis system is obtained.

A meteorological multipurpose station was formed on a remote site. Sensor elements of Vaisala company (WXT 510) were used. Sensors that enable standard meteorological measures were defined and purchased, and afterwards specific supplementary sensors were obtained as well. The following sensors were aimed at: wind speed sensors, sensors for wind direction with compass, pressure sensor, relative air humidity sensor, air temperature sensor, sensor for detection of precipitation and sensor of direct sun radiation. 


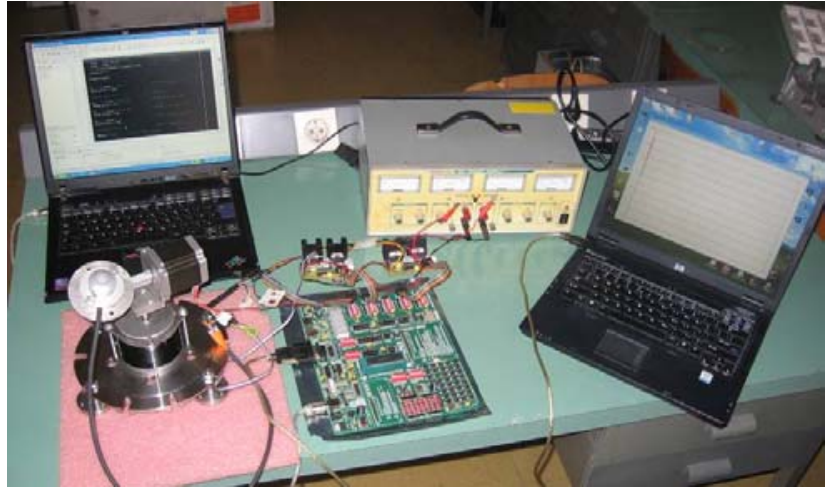

a)

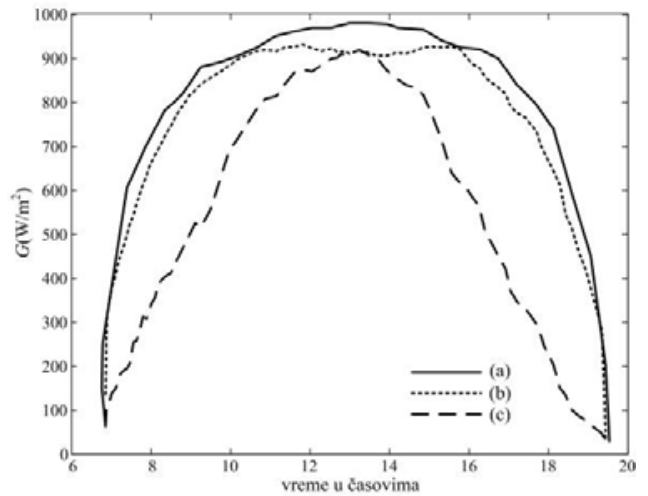

b)

Figure 29 (a) Laboratory prototype of realized rotating measuring system with two-axis rotation (b) Comparison of global sun radiation intensity measured by the system with two-axis rotation (a), with one axis rotation (b) with stationary measuring system directed towards south with $45^{\circ}$ tilt of receiving area (c)

The realized system for the measurement of direct sun radiation intensity is based on the QMS 101 Keep\&Zonen pyranometer, based on sensor degree and is an integral part of the meteorological station.

The realized microprocessor system for the temperature measurement serves to measure temperature of each PV module, and the referential temperatures of the ambient and relative air humidity, and is an integral part of a more complex measuringmonitoring PV system.

The realized system for the monitoring of PV solar panels position provides data on azimuth angle and PV solar panels platform elevation. This microprocessor system contains two contactless magnet sensors, one of which measures azimuth angle and the other that measures the elevation angle. The absolute measuring system corrects movement of solar panels in case that some mistakes were made in output actuating motors management, whose function is to precisely position PV solar panels towards the adopted program algorithm.

In the realized system for the PV module currency measurement, currency measurement is performed by means of integral circuits based on Hall effect, and as contactless sensors one uses magnet sensors. These integral sensors measure magnet field formed by the currency in the belt on the printed circuit board.

The realized measurement systems are a part of a new hybrid variant of the measurement system (Figure 30). Measuring-communication system in small PV power plants enables measurement of several different physical parameters, such as temperature, voltage, currency, intensity of sun radiation, and in rotating systems the current position according to the azimuth and elevation, speed, wind direction, etc. All necessary data are gathered, processed, saved in measuring - sensor block, and are then automatically transmitted to the central control microprocessor system.

The suggested variant of the wireless measuring-control system in its structure and adopted contemporary solutions is primarily designed for use in rotating PV systems, whereby it functionally supports application in all fixed PV systems of lower power. The new hybrid variant of the measurement system is applied in the development of the basic dual axis rotational positioner with $5 \mathrm{kWp}$ of power, whose realization is underway.

Two ways of quick and correct detection of defects in photovoltaic modules and cells during exploitation by means of thermovision camera were realized. The first detection method is based on the original thermal drive obtained by convection, that is, by hot air streaming, which is used for generation of thermal paths on locations of defects. Another suggested method is based on the generation of different hot and cold thermal fronts by means of original experimental assumptions realized by thermoelectrical modules which, combined with microprocessor circuit, generate different types of thermal waves (Figure 31a). In that case, if there are defects the structure of thermal waves on the surface of the cells is changed. These thermal changes were detected by means of the thermovision camera by visualization of thermal front on the surface on the module (Figure 31b).

Rotating positioners which are designed, realized and tested in the Laboratory for energy electronics at the Faculty of Electrical Engineering in Niš are the following:

a) Defined by rotation: two-axis positioners;

b) Defined by manner of tracking: step tracking positioners; 
c) Defined by the type of control: microprocessor systems with time control (applying astronomy method, that is with the control in open loop).

Figure 32 shows realized dual-axis rotating system with photovoltaic panels as receivers. Realized dual axis rotating system is envisaged for the application in the independent photovoltaic systems. It belongs to small, easy transferable systems with maximally projected load of $200 \mathrm{~kg}$, with possible rotation of the photovoltaic panels surface of $4 \mathrm{~m}^{2}$, and is characterized by compactness, reliability, easy mounting, and relatively low cost. Realized system operates by sequential (discontinual) manner during its positioning, therefore, the system is active (consumes energy) only in short time intervals. This is an easy positioner that is able to position at $240^{\circ}$ in azimuth and $90^{\circ}$ in elevation. The realized rotating system uses monocrystalline and polycrystalline photovoltaic modules with $230 \mathrm{~W}$ of power, manufactured in Eurener in Spain.

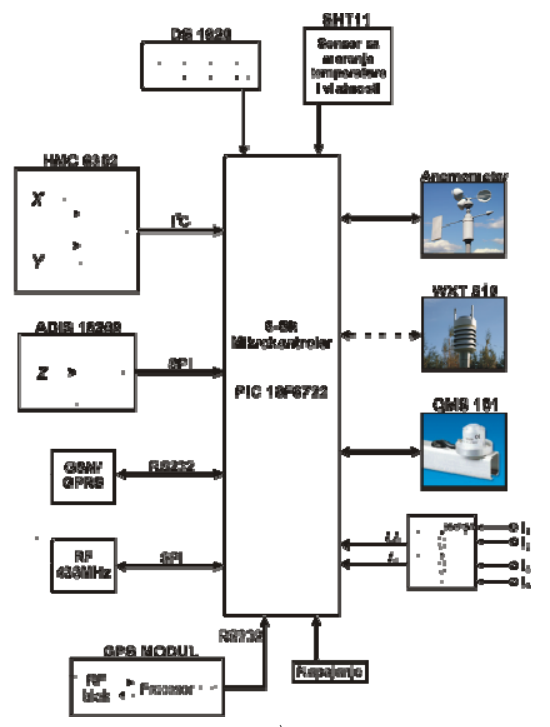

a)

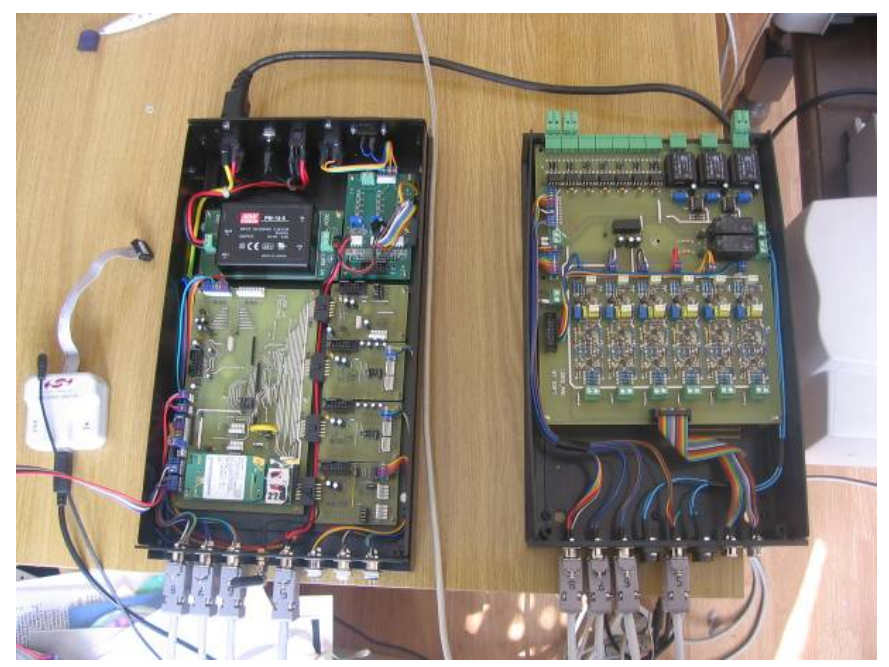

b)

Figure 30. (a) Realized measurement-communication system with all sensors; (b) Realized measurement-communication system

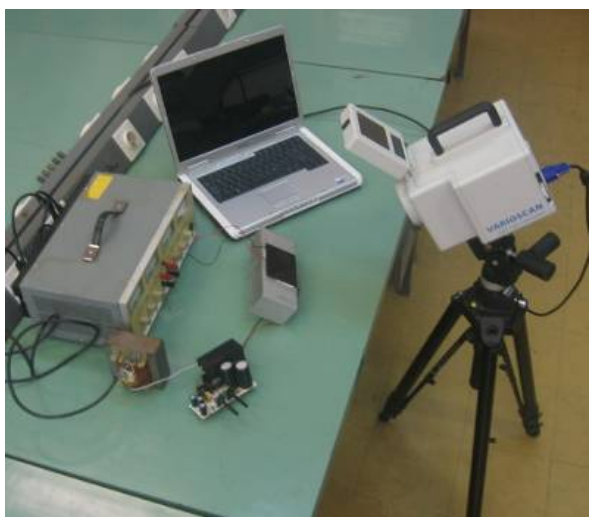

a)

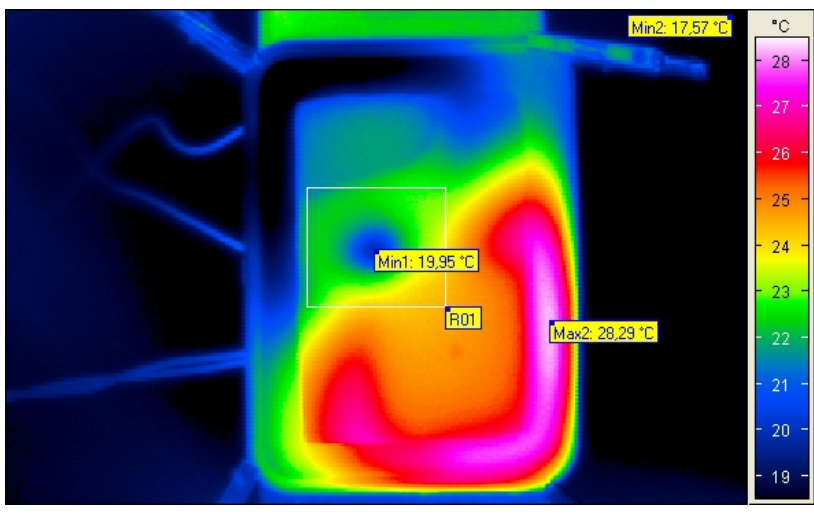

b)

Figure 31. (a) Realized thermovision measuring system; (b) Temperature distribution on the surface of the solar cell with simulated defect: generating thermal front on one, and cold front on the other side of the solar cell using two 


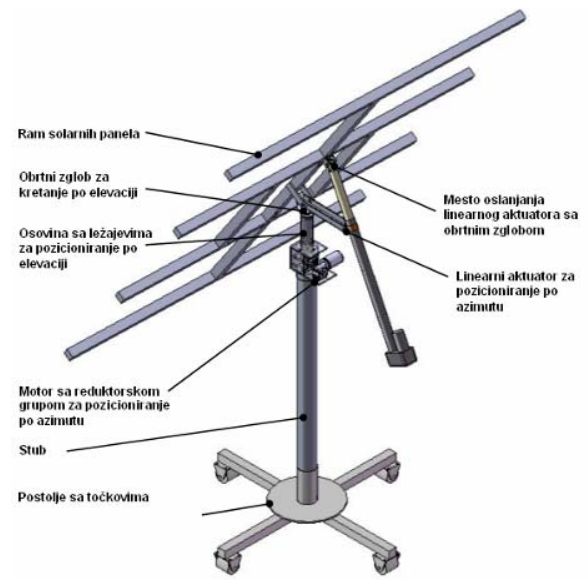

a)

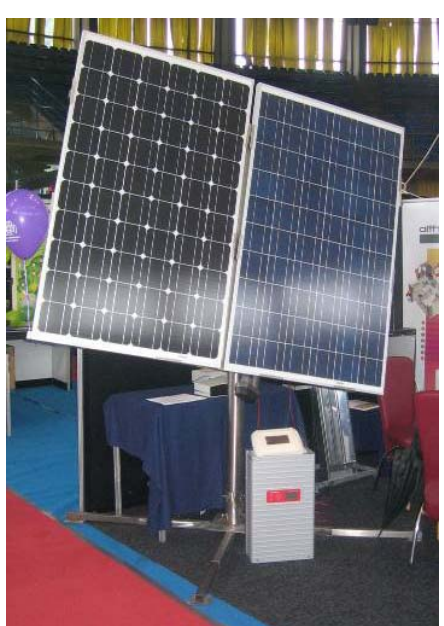

b)

Figure 32. Complete design of easy positioner which is (a) projected and (b) realized

The described solution is a part of the experimental combined PV solar plant, with power of about $1 \mathrm{~kW}(4 \times 230 \mathrm{~W})$, currently implemented at the Faculty of Electrical Engineering in Niš. It is comprised of the rotating and fixed part of the system $(2 \times 0,5 \mathrm{~kW})$, with monocrystalline and polycrystalline silicon PV modules. PV modules of the rotating and fixed part of the system are used to charge the battery block of $12 \mathrm{~V} / 170 \mathrm{Ah}$, by chargers. For the connection of different $\mathrm{AC}$ consumers the inverter with maximum power of $1000 \mathrm{~W}$ is used. The aim of the current research in the Laboratory for energy electronics is to develop, implement and monitor a distributed network, modular rotating photovoltaic system, with the power of $5 \mathrm{kWp}$, as a basic modular unit for the realization of PV solar plant of higher power, that are created by connecting several basic units. Our current activity is focused on designing an innovative rotating high-capacity positioner, by applying mechanical structure of the positioner with two axis rotation. The aim of implementing this system is to connect it to the grid. Dimensions of such a positioner, as well as the capacity of the rotating system are specified for 12 photovoltaic modules and the PV solar plant would be composed of 9 rotating units.

\section{CONCLUSION}

Intensive development of solar energy in Serbia began in 1973 after the outbreak of the big world energy crisis. The Republic of Serbia has favorable climate conditions for use of solar energy. A legislative for use of renewable energy sources which is in line with the European regulations in the same area has been enacted in Serbia. Flat plate collectors are manufactured by several companies in Serbia, while solar collectors for low temperature conversion of sun radiation are rarely used. Serbia has installed four demo PV solar plants with power of up to 5 kWp on schools in Ruma, Varvarin, Belgrade and Kula. PV systems are rarely used in private households or other facilities in Serbia. Serbia mainly imports PV modules and other equipment for the use of PV systems. It also has several houses built by using the principles of solar architecture. Research in Serbia in the area of solar energy is conducted by the researchers at the Faculty of Science, Faculty of Electrical Engineering and Civil Engineering in Niš, Technical faculty „M. Pupin“ in Zrenjanin, Institutute „M. Pupin“ in Belgrade, etc. In the Laboratory for solar energy at the Faculty of Science and Mathermatics in Niš research is conducted in low temperature, hybrid and photovoltaic conversion of sun radiation. At the Faculty of Electrical Engineering in Niš research is conducted in tracking PV system. The Faculty of Civil Engineering in Niš carries out research on flat plate and compound parabolic collectors. Solar energy in Serbia was the main topic of many conferences and was also researched by many international projects and projects financed by the Ministry of Science; also a number of books, a lot of graduation papers, specialist and master thesis and doctoral dissertations on this topic have been published.

\section{REFERENCE}

[1] T. Pavlović, B. Čabrić, Physics and techniques of solar energy, Građevinska knjiga, Belgrade 2006. 
[2] J. M. Radosavljević, T. M. Pavlović, M. R. Lambić, Solar energy and sustainable development, Građevinska knjiga, Belgrade, 2010.

[3] M. Lambic, Solarica Serbica, Društvo za sunčevu energiju-Serbia Solar, Zrenjanin, Serbia 2010.

[4] T. Pavlović, Development of Solar Energetics in Serbia, SANU, Belgrade 2002.

[5] National Assembly of the Republic of Serbia, Energy law, Official Gazette of the Republic of Serbia 84/04; 2004. Available online at: http://www.parlament.gov.rs/content/eng/ [in Serbian].

[6] National Assembly of the Republic of Serbia, Regulation for incentive measures for privileged producers of electricity; 2008. Available at: http://www.mre.gov.rs/

[7] T. Pavlović, B. Čabrić, Solar Energy, Filozofski fakultet, Niš 1994.

[8] M. Lambić at all, Studija o proceni ukupnog solarnog potencijala - solarni Atlas i mogućnosti „proizvodnje” i korišćenja solarne energije na teritoriji AP Vojvodine, Pokrajinski sekretarijat za energetiku i mineralne sirovine, Republika Srbija Autonomna Pokrajina Vojvodina 2011.

[9] M. Lambić, I. Tasić, N. Pavlović, D. Stojićević, Solarna energetika - instalacije i objekti, Srbija solar, Zrenjanin 2006.
[10] T. Pavlović, D. Milosavljević, A. Radivojević, M. Pavlović, Comparison and assessment of electricity generation capacity for different types of PV solar plants of $1 M W$ In Soko Banja, Serbia, Thermal Science, 15-3 (2011), 605-618, DOI:10.2298/TSCI110322065P.

[11] D. Marković, B. Čeperković, A. Vlajčić and S. Ressl, The White Book of the Electric Power Industry of Serbia, PE Electric Power Industry of Serbia, Public Relations Sector, Belgrade 2011.

[12] B. Lalović, T. Pavlović, J. Van Dine, Z. Kiss, L. R. Shiue, T. Tonon, B. Sieb, W. Xuanzhi, Amorphous silicon solar cells on anodically oxidized aluminium substrate, Solar Cells, 26 (1989), 263-268.

[13] M. Pucar, Bioklimatska arhitektura, Institut za urbanizam i arhitekturu Srbije, Beograd, 2006.

[14] V. Kosorić, Aktivni solarni sistemiprimena u materijalizaciji omotača energetski efikasnih zgrada, Građevinska knjiga, Beograd, 2007.

[15] T. Pavlović, A. Ignatiev, Optical and microstructural properties of anodically oxidized aluminum, Thin Solid Films, 138 (1986) 97-109.

[16] T. Pavlović, A. Ignatiev, Optical properties of spectrally selective anodically coated electrolitically colored aluminum surfaces, Solar Energy Materials, 16 (1987) 319-331.

\section{СОЛАРНА ЕНЕРГИЈА У СРБИЈИ}

Апстракт: У раду се обрађује развој соларне енергије, потенцијал сунчевог зрачења и законски оквир који регулише коришћење сунчевог зрачења у Србији. Такође је дат опис тренутног стања у области нискотемпературне и фотонапонске конверзије сунчевог зрачења и соларне архитектуре у Србији. Посебна пажња посвећена је развоју соларне енергије у Нишу, опису лабораторија и резултата истраживања соларне енергије на Природно-математичком факултету, Електротехничком факултету и Грађевинском факултету Универзитета у Нишу.

Кључне ријечи: соларна енергија у Србији, колектори са равном плочом и сложени параболични колектори, фотонапонске соларне електране, ротирајући фотонапонски систем. 